Creative Commons User License: CC BY-NC-ND

Abstracted by: EBSCOhost, Electronic Journals Service (EJS),

Google Scholar, Journal Seek, Scientific Commons,

Food and Agricultural Organization (FAO), CABI and Scopus
Journal of Agricultural Extension

Vol. 23 (2) April, 2019

ISSN(e): 24086851; ISSN(Print); 1119944X

http://journal.aesonnigeria.org

http://www.ajol.info/index.php/jae

Email: editorinchief@aesonnigeria.org

http://eoi.citefactor.org/10.11226/v23i2

\title{
Mass Media Utilization by Poultry Farmers in Anambra State, Nigeria
}

https://dx.doi.org/10.4314/jae.v23i2.1

\section{Nwalieji, Hyacinth Udeanya}

Department of Agricultural Economics and Extension, Chukwuemeka Odumegwu Ojukwu University (former Anambra State University), Igbariam Campus, Nigeria

E-mail: nwalieji73@yahoo.com, hu.nwalieji@coou.edu.ng +2347033994751

\section{Ezeakunne, Celestina Chiamaka}

Department of Agricultural Economics and Extension, Chukwuemeka Odumegwu Ojukwu University (former Anambra State University), Igbariam Campus, Nigeria

E-mail: datacafe1@yahoo.com +2347033575157

\section{Enwelu, Innocent A.}

Department of Agricultural Extension University of Nigeria, Nsukka, Enugu State, Nigeria Email: enwachonamin@yahoo.com +2348035090033

\section{Okeke, Margaret Ngozi}

Department of Agricultural Economics and Extension, Chukwuemeka Odumegwu Ojukwu University (former Anambra State University), Igbariam Campus, Nigeria

E-mail: megngookeke@gmail.com +2348065845408

\section{Udemezue, Joseph Chigozie.}

National Root Crops Research Institute, Umudike, PMB7006 Umudike Abia State, Nigeria

E-mail: udemezuej@gmail.com +2348038971076

\section{Uzuegbunam, Christopher Osita}

Department of Agricultural Economics and Extension, Chukwuemeka Odumegwu Ojukwu University (former Anambra State University), Igbariam Campus, Nigeria

E-mail: chrisuzuegbunam@yahoo.com +2348036748377

\section{Abstract}

The study assessed mass media utilization by poultry farmers in Anambra State. All poultry farmers in Anambra State formed the population of the study. Multi-stage sampling procedure was used in selection of 120 respondents for the study. Data were collected from primary source through the use of interview schedule. Data were analysed using percentage, mean score and factor analysis. The findings showed that about $98 \%$ of the respondents were literate, while the mean age was 34years and the mean poultry farming experience was 4 years. The mean number of birds reared was 114 birds, while the mean annual income was $\mathrm{N268,450.00}$ and the mean annual number of visits by extension agents was 2 times. The major mass media channels used were newspaper, radio, agricultural books, television, agricultural journal, mobile phone and internet. There were high level of mass media utilization in information on pests/diseases outbreak and control $(\bar{x}=2.38)$, chicks brooding techniques $(\bar{x}=2.37)$, feeding and feed formulation $(\bar{x}=2.27)$, general housing construction $(\bar{x}=2.13)$ and daily routine management practices $(\bar{x}=$ 2.09).Inadequate fund, irregular power supply and lack of needed poultry information in newspapers, radio. were the major constraints to effective utilization of mass media by poultry farmers. Message and information access were identified as the major factors militating mass media utilization in the area. The need to strengthen extension delivery system particularly the communication and input delivery components was recommended.

Keywords: Mass media, utilization, poultry farmers 
Creative Commons User License: CC BY-NC-ND

Abstracted by: EBSCOhost, Electronic Journals Service (EJS),

Google Scholar, Journal Seek, Scientific Commons,

Food and Agricultural Organization (FAO), CABI and Scopus
Journal of Agricultural Extension

Vol. 23 (2) April, 2019

ISSN(e): 24086851; ISSN(Print); 1119944X

http://journal.aesonnigeria.org

http://www.ajol.info/index.php/jae

Email: editorinchief@aesonnigeria.org

\section{Introduction}

Poultry production is mainly for meat and eggs production. Poultry farming involves the raising of domesticated birds such as chickens, ducks, turkeys and geese for the purpose of family meat or eggs for food (Adeyemo and Onikoyi, 2012). Poultry are farmed in great numbers with chickens being the most numerous. More than 50 billion chickens are raised annually as a source of food, for both their meat and their eggs (National Centre for Biotechnical Information (NCBI), 2016).

Poultry meat production is a complex and technologically advanced system seeking continual improvement in genetic material, and nutrition and husbandry techniques. Today's poultry are the product of complex, scientifically based programmes aimed at producing more meat or eggs while consuming less feed. For smallholder farmers in developing countries (especially in low income, food-deficient countries (LIFDC), poultry farming represents one of the few opportunities for saving, investment and security against risk (Bruce, 2013). The poultry sector continues to grow and industrialize in many parts of the world. An increasing population, greater purchasing power and urbanization have been strong drivers of growth (Heise, Crisan and Theuvsen, 2015).

Advances in breeding have given rise to birds that meet specialized purposes and are increasingly productive, but that need expert management. The development and transfer of feed, slaughter and processing technologies have increased safety and efficiency, but favour large-scale units rather than small-scale producers. These developments have led the poultry industry and the associated feed industry to scale up rapidly, to concentrate themselves close to input sources or final markets, and to integrate vertically. One element of the structural change has been a move towards contract farming in the rearing phase of boiler production, allowing farmers with mediumsized flocks to gain access to advanced technology with a relatively low initial investment through adequate information (FAO, 2016).

Information and communication are essential ingredients needed for effective transfer of technologies that are designed to boost agricultural production. For farmers to benefit from such technologies, they must first have access to them and learn how to effectively utilize them in their farming systems and practices. This should be the function of agricultural extension agencies all over the world. These extension agencies make use of different approaches, means and media in transferring improved agricultural technologies to the end users (farmers). The various approaches or means according to Asiabaka (2012) are print and electronic media. The print media include circulars, posters, leaflets, bulletins, newspapers and journals, while the electronic media consist of television, radio, internet, video and telephone. Mass media include print media such as books, magazines, newspapers, and electronic media such as audio, television, movies, and the internet (Mgbakor, lyobor and Uzendu, 2013).

Mass media methods in agricultural information dissemination generally, are useful in reaching a wide audience at a very fast rate. They are useful as sources of agricultural information to farmers and as well constitute methods of notifying farmers of new developments and emergencies. They could equally be important in stimulating farmers' interest in new ideas and practices (Sharma, 2012). Mass media are important in providing information for enabling the rural community to make informed decision regarding their farming activities, especially in the rural areas of developing countries (Enwelu, Enwereuzor, Asadu, Nwalieji and Ugwuoke, 2017). 
Creative Commons User License: CC BY-NC-ND

Abstracted by: EBSCOhost, Electronic Journals Service (EJS),

Google Scholar, Journal Seek, Scientific Commons,

Food and Agricultural Organization (FAO), CABI and Scopus
Journal of Agricultural Extension

Vol. 23 (2) April, 2019

ISSN(e): 24086851; ISSN(Print); 1119944X

http://journal.aesonnigeria.org

http://www.ajol.info/index.php/jae

Email: editorinchief@aesonnigeria.org

http://eoi.citefactor.org/10.11226/v23i2

Hasan and Sharma (2011) noted that mass media are used to reach a large number of people quickly. It is particularly useful in making large number of people aware of new ideas and practices, or alerting them to sudden emergencies. While the amount of detailed information that can be transmitted through mass media is limited, they can serve as an important and valuable function in stimulating farmers' interest in new ideas. Once stimulated or made aware through mass media, farmers may seek additional information from neighbours, friends, extension agents or progressive farmers in the area (Sharma, 2012). Asiabaka (2012) stated that extension services use mass media because of the high speed and low cost with which information can be communicated over a wide area. The information technology is a tremendous power that could be harnessed by organizations for the benefit of mankind.

The high demand for poultry meat and eggs has really proven that poultry farming in Nigeria is indeed a very lucrative business. Irrespective of its importance in Nigeria, poultry farming still encounter a lot of setbacks due to non- availability of adequate information source. This development therefore, underscores the need for enhanced mass media use by poultry farmers in poultry farming information dissemination in Nigeria. The extension organizations in developing countries have two major problems when it comes to face to face contacts with the farmers and researchers: first, physical distance and second, lack of transportation facilities (Ani, Umunakwe, Ejiogu -Okereke, Nwakwasi and Aja, 2017).

The potentials of mass media such as speed, mass coverage and low cost in the dissemination of information further necessitate their use in agriculture. This therefore, calls for a system which allows adequate information flow from researchers to farmers and vice-versa. In Anambra State, poultry farmers abound and there is availability of different types of mass media. The extent through which these poultry farmers utilize the various kinds of mass media for proper transfer and adoption of technology to boost poultry production in the area is not yet known. This study therefore assessed the mass media utilization by poultry farmers in Anambra State, Nigeria. Specifically, the objectives were to:

i. identify socio-economic characteristics of the poultry farmers;

ii. ascertain various channels of mass media used by poultry farmers;

iii. examine types of poultry farming technologies sourced through the various mass media channels;

iv. determine level of mass media utilization by poultry farmers in poultry farming technology adoption; and

v. identify factors that militate against effective utilization of mass media by poultry farmers.

\section{Methodology}

The study was carried out in Anambra State of Nigeria. Anambra State is located in the SouthEastern region of Nigeria between longitude $6^{\circ} 36^{\prime} \mathrm{E}$ and $7^{\circ} 21^{\prime} \mathrm{E}$ and latitude $5^{\circ} 38^{\prime} \mathrm{N}$ and $6^{\circ} 47^{\prime} \mathrm{N}$. It has a land area of about 4,415.54 square kilometres, $70 \%$ of which are rich for agricultural production. The State has twenty-one Local Government Areas which are further divided into four agricultural zones; Aguata, Anambra, Awka and Onitsha zones. The climate can generally be described as tropical with two seasons, the wet and dry seasons. The major occupation of the people is trading and farming. The majority of farmers are producing at small-scale range. Livestock include goat, sheep, pig and poultry, domesticated mainly at small scale except poultry which is being produced in small, medium and large scales. Poultry farming is very important in the life of the populace. It provides employment and additional income for many people especially (women and youths) because of its quick return on investment and less space requirement. Anambra State has about 23 mass media stations which include; Sun Publishing limited, Odenigbo 99.1Fm, Blaze 99.5Fm, Punch Publishing limited, Trade Media, Rhythm 97.5Fm. All 
Creative Commons User License: CC BY-NC-ND

Abstracted by: EBSCOhost, Electronic Journals Service (EJS),

Google Scholar, Journal Seek, Scientific Commons,

Food and Agricultural Organization (FAO), CABI and Scopus
Journal of Agricultural Extension

Vol. 23 (2) April, 2019

ISSN(e): 24086851; ISSN(Print); 1119944X

http://journal.aesonnigeria.org

http://www.ajol.info/index.php/jae

Email: editorinchief@aesonnigeria.org

http://eoi.citefactor.org/10.11226/v23i2

these media stations make use of radio, television, internet, newspapers, recordings, online media, as information communication channels.

The population of the study comprised all poultry farmers in Anambra State. Multi-stage sampling procedure was used in the selection of 120 poultry farmers for the study. Stage one involved a purposive selection of three agricultural zones; Awka, Aguata and Onitsha from the four zones that exist in Anambra State, based on the existence of major urban cities and the preponderance of poultry farmers in these cities. In stage two, two blocks were selected from each of the selected zones using simple random sampling technique. This gave six blocks selected. Stage three involved selection of two circles from each of the selected blocks using simple random sampling technique to arrive at 12 circles being selected. Finally, in stage four, 10 poultry farmers were selected randomly in each of the selected circles in Anambra State to give 120 poultry farmers.

Data for this study were collected using primary source through an interview schedule. The interview schedule was divided into (5) sections based on the objectives of the study. Relevant questions were formulated under each section to provide data for analysis. Two enumerators were trained on the content of the interview schedule to assist the researcher in data collection.

The IBM-SPSS Statistics software (Version 16) was used to analyse the data. Objectives 1, 2, 3 and 4 were realized using descriptive statistics such as percentage and mean score. Objective 5 which identified the major factors militating against effective utilization of mass media by poultry farmers was analysed using mean statistics and factor analysis.

\section{Results and Discussion}

\section{Socio-Economic Characteristics of Poultry Farmers}

Table 1 reveals that $39.1 \%$ of the respondents were within the age range of $20-29$ years while the mean age was $33.8 y e a r s$. This implies that young people of economically active age, constitute the greater population of poultry farmers. Greater proportion $(50.8 \%)$ of the poultry farmers were male. This result implies that more men are involved in poultry production than women. This finding agrees with the findings of Ariyo, Ariyo, Okelola, Aasa, Awotide, Aaron, and Oni (2013) that men are more into farming than women. Table 1 indicates that the majority $(54.5 \%)$ of the 
Creative Commons User License: CC BY-NC-ND

Abstracted by: EBSCOhost, Electronic Journals Service (EJS),

Google Scholar, Journal Seek, Scientific Commons,

Food and Agricultural Organization (FAO), CABI and Scopus
Journal of Agricultural Extension

Vol. 23 (2) April, 2019

ISSN(e): 24086851; ISSN(Print); 1119944X

http://journal.aesonnigeria.org

http://www.ajol.info/index.php/jae

Email: editorinchief@aesonnigeria.org

\section{Table 1: Socio-economic characteristics}

\begin{tabular}{|c|c|c|}
\hline Variable & Percentage $(\%)(n=120)$ & Mean $(\bar{x})$ \\
\hline \multicolumn{3}{|l|}{ Age (years) } \\
\hline $10-19$ & 6.7 & \\
\hline $20-29$ & 39.1 & \\
\hline $30-39$ & 31.7 & 33.88 \\
\hline $40-49$ & 15.0 & \\
\hline $50-59$ & 7.5 & \\
\hline \multicolumn{3}{|l|}{ Sex } \\
\hline Male & 50.8 & \\
\hline Female & 49.2 & \\
\hline \multicolumn{3}{|l|}{ Marital status } \\
\hline Married & 54.5 & \\
\hline Single & 36.4 & \\
\hline Widowed & 3.3 & \\
\hline Divorce & 5.0 & \\
\hline \multicolumn{3}{|l|}{ Educational qualification } \\
\hline No formal Education & 3.2 & \\
\hline Primary School Attempted & 3.2 & \\
\hline Primary School Completed & 11.3 & \\
\hline Secondary School Attempted & 32.3 & \\
\hline Secondary School Completed & 37.1 & 11.8 \\
\hline NCE/OND & 14.5 & \\
\hline HND/First Degree & 19.5 & \\
\hline \multicolumn{3}{|l|}{ Household size (number) } \\
\hline $1-5$ & 59.2 & \\
\hline $6-10$ & 35.8 & \\
\hline $11-15$ & 4.2 & 5 persons \\
\hline $16-20$ & 0.8 & \\
\hline \multicolumn{3}{|l|}{ Farming experience (years) } \\
\hline $1-5$ & 80.8 & \\
\hline $6-10$ & 16.7 & 3.71 \\
\hline $11-15$ & 9.5 & \\
\hline \multicolumn{3}{|c|}{ Number of visit by extension per year } \\
\hline Nil & 56.7 & \\
\hline $1-2$ times & 15.0 & \\
\hline 3-4 times & 14.1 & 2 \\
\hline $5-6$ times & 11.7 & \\
\hline 7-8 times & 0.8 & \\
\hline 9-10 times & 1.7 & \\
\hline \multicolumn{3}{|l|}{ Number birds reared } \\
\hline $1-100$ & 68.3 & \\
\hline $101-200$ & 20.0 & 114 \\
\hline $201-300$ & 8.3 & \\
\hline $301-400$ & 1.7 & \\
\hline $401-500$ & 1.7 & \\
\hline \multicolumn{3}{|l|}{ Income earned per year (Naira) } \\
\hline $1000-200000$ & 70.8 & \\
\hline $201000-400000$ & 10.0 & \\
\hline $401000-600000$ & 5.9 & $268,450.00$ \\
\hline $601000-800000$ & 3.3 & \\
\hline $801000-1000000$ & 7.5 & \\
\hline 1000001 and above & 2.5 & \\
\hline
\end{tabular}

Source: Field survey, 2017

respondents were married and this confirms the findings of Akinnusi, Sodiya, and Adamu (2018) that married people accounts for the majority of poultry farmers. The greater proportion (37.1\%) of the respondents completed secondary school. This implies that poultry farmers in the area are educated and are likely to access agricultural information disseminated through various mass media channels or forms. Table 1 also shows that a majority $(59.2 \%)$ had $1-5$ persons and the mean household size was 5 persons. This is an indication that poultry farmers have a fair household size which could probably supply the needed farm labour. The majority $(80.8 \%)$ of the respondents had 1-5 years of farming experience, while the mean farming experience was 3years. 
Creative Commons User License: CC BY-NC-ND

Abstracted by: EBSCOhost, Electronic Journals Service (EJS), Google Scholar, Journal Seek, Scientific Commons,

Food and Agricultural Organization (FAO), CABI and Scopus
Journal of Agricultural Extension

Vol. 23 (2) April, 2019

ISSN(e): 24086851; ISSN(Print); 1119944X

http://journal.aesonnigeria.org

http://www.ajol.info/index.php/jae

Email: editorinchief@aesonnigeria.org

http://eoi.citefactor.org/10.11226/v23i2

This implies that greater number of the respondents have not been into poultry farming for a long time.

Table 1 further reveals that $56.7 \%$ accounted for no extension visit at all in the last one year, and the mean number of visits was2 times. This is very poor, considering that poultry farming is an information dependent venture. This result is in accordance with the findings of that inadequate extension contacts is one of the major constraints faced by poultry farmers in Nigeria. The majority $(68.3 \%)$ of the farmers kept below $100 \%$ of birds, and the mean number of birds reared was $114 \mathrm{birds}$. This result implies that most of the poultry farmers are small scale farmers. This agreed with the report of Olagunju and Babatunde (2011) that the population of Nigerian that engaged in poultry production are mostly subsistence and small or medium sized farms. Also, the majority $(70.8 \%)$ of the farmers earned between $\$ 1,000$ - $\$ 200,000$ per year and the mean income was \#268, 450. This implies that the farmers that engage in poultry production earn reasonable income which will better their life.

\section{Channels of Mass Media Used}

The information in Table 2 shows that the major mass media channels used by the respondents were newspaper (63.3\%), Radio (76.7\%), agricultural books (59.2\%), television (75. 0\%), agricultural journal (59.2\%), mobile phone $(77.5 \%)$, and internet $(66.7 \%)$. The major mass media channels not used by the farmers included; farm magazine (70.8\%), agricultural billboards $(76.7 \%)$, cinema viewing centre $(84.0 \%)$, farm bulletin $(77.5 \%)$, farm posters $(78.3 \%)$. This shows that newspapers, radio, agricultural books, television, agricultural journal, mobile phones, internet are more popular among the poultry farmers. These findings are in line with the work of Koyenikan (2011) and Oladeji (2011), who reported that radio, mobile phone, agriculture books, television, bulk sms were the mass media forms/ channels mostly used by poultry farmers in Nigeria. Chah, Odo, Asadu, and Enwelu (2013) also identified radio as the major source of information on climate change by the poultry farmers.

According to Asiabaka (2012), mass media methods in agricultural information dissemination generally, are useful in reaching a wide audience at a very fast rate. They are useful as sources of agricultural information to farmers and as well constitute methods of notifying farmers of new developments and emergencies.

Table 2: Channels of mass media sources used

\begin{tabular}{ll}
\hline Source & Used \% \\
\hline Newspapers & 63.3 \\
Radio & 76.7 \\
Agricultural books & 59.2 \\
Television & 75.0 \\
Agricultural journal & 59.2 \\
Mobile phone & 77.5 \\
Internet & 66.7 \\
Farm magazine & 29.2 \\
Agricultural billboards & 23.3 \\
Cinema viewing centre & 16.0 \\
Farm bulletin & 22.5 \\
Farm posters & 21.7 \\
\hline
\end{tabular}

Source: Field survey, 2017 
Creative Commons User License: CC BY-NC-ND

Abstracted by: EBSCOhost, Electronic Journals Service (EJS),

Google Scholar, Journal Seek, Scientific Commons,

Food and Agricultural Organization (FAO), CABI and Scopus
Journal of Agricultural Extension

Vol. 23 (2) April, 2019

ISSN(e): 24086851; ISSN(Print); 1119944X

http://journal.aesonnigeria.org

http://www.ajol.info/index.php/jae

Email: editorinchief@aesonnigeria.org

\section{Type of Poultry Farming Technologies Received from Mass Media Channels}

Table 3 reveals that respondents received different types of poultry information from different mass media channels. On chicks brooding and brooding techniques, respondents indicated that they received such information mainly from mobile phone (27.5\%), television $(20.0 \%)$ and radio (19.2\%). On vaccination (information on pests and diseases outbreak, control, quarantine and vaccination of birds), respondents indicated that they received information mainly through mass media sources such as mobile phone (29.2\%), television (20.0\%) and internet (18.3\%).

On feed and feed formulation for birds, respondents used mainly mobile phone $(33.3 \%)$ and television $(15.0 \%)$ as their mass media sources. On daily routine management practices such as; provision of disinfectants for footbath, inspection of birds, lighting of poultry pen, taking daily stock record., and the respondents used mostly the mobile phone (30.8\%) as the mass media source. Information on general housing such as housing equipment, indoor with high welfare, stocking densities and construction of poultry pen; use of battery cage, deep-litter, among others reveals that $28.3 \%$ of the farmers mainly used mobile phone as their mass media source. Also information on pen lightening showed mobile phone $(30.0 \%)$ as their major mass media source. This implies that poultry farmers mainly use mobile phone among others in sourcing poultry farming technologies. This result asserts that electronic sources are better mass media alternative for farm information possibly due to their appeal to more sensory organs than the print, relative cost advantage over other sources and less dependence on users' literacy level (Akinnusi, Sodiya, and Adamu, 2018).

Table 3: Type of poultry farming technologies received from mass media channels

\begin{tabular}{|c|c|c|c|c|c|c|c|c|c|}
\hline Poultry farming technologies & $\begin{array}{l}\circ 0 \\
\stackrel{0}{2} \\
\text { 은 }\end{array}$ & 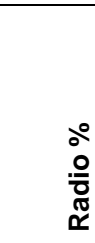 & $\stackrel{\circ}{\gtrless}$ & $\begin{array}{l}\stackrel{0}{c} \\
\frac{0}{0} \\
\frac{1}{0} \\
\frac{0}{0} \\
\frac{0}{0} \\
\sum\end{array}$ & $\begin{array}{l}\circ \\
\frac{0}{2} \\
\frac{0}{d} \\
\frac{0}{\pi} \\
\frac{0}{0} \\
\frac{0}{0} \\
\frac{3}{2}\end{array}$ & 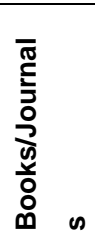 & 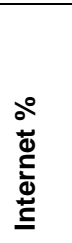 &  & $\begin{array}{l}\frac{\infty}{2} \\
\frac{\Phi}{0}\end{array}$ \\
\hline $\begin{array}{l}\text { Information on chicks brooding and } \\
\text { brooding techniques. }\end{array}$ & 12.5 & 19.2 & 20.0 & 27.5 & 3.3 & 4.2 & 11.7 & 0.8 & 0.8 \\
\hline Vaccination: & 2.5 & 15.0 & 20.0 & 29.2 & 5.0 & 5.8 & 18.3 & 3.3 & 0.8 \\
\hline $\begin{array}{l}\text { Information on feeding/feed } \\
\text { formulation for birds }\end{array}$ & 11.7 & 14.2 & 15.0 & 33.3 & 9.2 & 9.2 & 5.0 & 1.7 & 0.8 \\
\hline Daily routine management practices & 12.5 & 10.8 & 12.5 & 30.8 & 10.0 & 12.5 & 9.2 & 0.8 & 0.8 \\
\hline General housing information & 15.8 & 14.2 & 13.3 & 28.3 & 4.2 & 10.0 & 10.0 & 3.3 & 0.8 \\
\hline Information on lightening of pen & 16.7 & 11.7 & 9.2 & 30.0 & 7.5 & 6.7 & 11.7 & 5.8 & 0.8 \\
\hline Total & 71.7 & 85.1 & 90.0 & 179.1 & 39.2 & 31.7 & 65.9 & 15.7 & 4.8 \\
\hline
\end{tabular}

Source: Field survey, 2016 
Creative Commons User License: CC BY-NC-ND

Abstracted by: EBSCOhost, Electronic Journals Service (EJS),

Google Scholar, Journal Seek, Scientific Commons,

Food and Agricultural Organization (FAO), CABI and Scopus
Journal of Agricultural Extension

Vol. 23 (2) April, 2019

ISSN(e): 24086851; ISSN(Print); 1119944X

http://journal.aesonnigeria.org

http://www.ajol.info/index.php/jae

Email: editorinchief@aesonnigeria.org

\section{Level of Mass Media Utilization in Poultry Farming Technologies}

Table 4 shows that the farmers had high level of mass media utilization in the following poultry farming technologies, information on pests/diseases outbreak, control, quarantine and vaccination of birds $(\bar{x}=2.38)$, chicks brooding and brooding techniques $(\bar{x}=2.37)$, feeding and feed formulation $(\bar{x}=2.27)$, general housing construction $(\bar{x}=2.13)$, daily routine management practices $(\bar{x}=2.09)$. Only information on pen lightening $(\bar{x}=1.91)$ had low utilization. This result implies that the level of mass media utilization in poultry farming technologies is high in many aspects of poultry technologies especially in the areas of pests/diseases control, chicks brooding techniques, feeding and feed formulation. The finding is in line with Akinbile, Akinpelu, and Akwiwu (2013) which reported that utilization of climate information was high among the small scale poultry farmers who had access to information. Mass media however, is useful in making large number of people aware of new ideas and practices, or alerting them to sudden emergencies. They can also serve as an important and valuable function in stimulating farmer's interest in new ideas. According to Mbanaso, Agwu, Anyanwu, Ememandu and Asumugba (2013), source of information is significant to adopting practices that lead to better production.

Table 4: Level of mass media utilization in poultry farming technologies

Information on poultry farming technologies Std.

Mean Deviation

Information on pests/diseases outbreak, Control, quarantine and vaccination of birds

$2.38 \quad 0.624$

Information on chicks brooding and brooding techniques

$2.37 \quad 0.744$

Information on feeding/feed formulation for birds

$2.27 \quad 0.670$

Information on General Housing construction

$2.13 \quad 0.744$

Information on daily routine management practices

$2.09 \quad 0.722$

Information on Pen Lightening

$1.91 \quad 0.722$

Source: Field survey, 2016

\section{Constraints to Effective Utilization of Mass Media by Poultry Farmers}

Table 5 shows that financial constraints $(\bar{x}=2.47)$, irregular power supply $(\bar{x}=2.30)$, lack of needed poultry information in newspapers, radio, $(\bar{x}=2.11)$, and illiteracy of farmers $(\bar{x}=2.06)$ were the major constraints identified that militate against effective utilization of mass media by poultry farmers in poultry farming technologies. This implies that most mass media devices require fund and power for purchasing and proper functioning; and the absence of these could interfere with their availability and use. However, the unavailability of credit could prevent rural farmers to purchase these devices, thus limiting their access to agricultural information. World Bank (2011) posited that lack of resources could impede the utilization of mass media by farmers. Ayanda (2013) also posited that constraints such as high cost of information creating gadgets (television, radio, computer), high level of poverty among farmers, readability problem among farmers, and inadequate power supply, all affect the use of mass media as source of agricultural information. 
Creative Commons User License: CC BY-NC-ND

Abstracted by: EBSCOhost, Electronic Journals Service (EJS),

Google Scholar, Journal Seek, Scientific Commons,

Food and Agricultural Organization (FAO), CABI and Scopus
Journal of Agricultural Extension

Vol. 23 (2) April, 2019

ISSN(e): 24086851; ISSN(Print); 1119944X

http://journal.aesonnigeria.org

http://www.ajol.info/index.php/jae

Email: editorinchief@aesonnigeria.org

\section{Table 5: Constraints to effective utilization of mass media by poultry farmers}

Constraint

Std.

\begin{tabular}{lcc} 
& Mean & Deviation \\
\hline Financial constraints & $2.47^{*}$ & 0.673 \\
Irregular power supply & $2.30^{*}$ & 0.866 \\
Lack of needed poultry information in newspapers, radio & $2.11^{*}$ & 0.807 \\
Illiteracy of farmers & $2.06^{*}$ & 0.802 \\
Orderly preference to entertainment based to serious & 1.94 & 0.748 \\
news & & \\
Resource Endowment & 1.88 & 0.758 \\
Ambiguity nature of message content & 1.88 & 0.805 \\
Poor access to information & 1.82 & 0.788 \\
\hline
\end{tabular}

${ }^{*} \bar{x}>2.00$. Source: Field survey, 2016

Table 6 shows the results of the rotated factor analysis indicating the extracted factors based on the responses of the respondents on the constraints to effective utilization of mass media in poultry farming technologies. Factors 1 and 2 were named message content and information access, respectively. Message content constraints included irregular power supply (0.450), lack of needed poultry information in newspapers, radio. (0.654), illiteracy of farmers $(0.596)$ and orderly preference to entertainment based to serious news (0.556). The findings imply that power failure had been a serious constraint to effective utilization of mass media. Also, poultry information can only be exploited by poultry farmers who have certain levels of formal education, therefore illiteracy of farmers affects their utilization of technology. This is in line with the finding of Akinnusi, Sodiya, and Adamu (2018), that high level of illiteracy as a major constraint to Information and Communication technology (ICT) utilization by farmers. Education enhances the ability to derive, decode and evaluate useful information for agricultural production.

Information access constraints included ambiguity nature of message content (0.634), poor access to information (0.716), resource endowment (0.415) and financial constraints $(0.612)$ as indicated in Table 6. This implies that financial constraints affect farmer's utilization of technologies requires financing so as to improve production. This agrees with the report of Mgbakor, lyobor and Uzendu (2013) that the small holder farmers lack economic capability to access and use relevant information. Another implication to this is that resource endowment affects poultry farmers' decision to adopt a new poultry technology. This is in line with the report of Okwu and lorkaa (2011) that farmers with large farms are likely to be better informed, richer and keener in searching for information on improved technologies. 
Creative Commons User License: CC BY-NC-ND

Abstracted by: EBSCOhost, Electronic Journals Service (EJS),

Google Scholar, Journal Seek, Scientific Commons,

Food and Agricultural Organization (FAO), CABI and Scopus
Journal of Agricultural Extension

Vol. 23 (2) April, 2019

ISSN(e): 24086851; ISSN(Print); 1119944X

http://journal.aesonnigeria.org

http://www.ajol.info/index.php/jae

Email: editorinchief@aesonnigeria.org

http://eoi.citefactor.org/10.11226/v23i2

Table 6: Constraints to effective utilization of mass media by poultry farmers

\begin{tabular}{lcc}
\hline Problem & $\begin{array}{c}\text { Factor1: } \\
\text { Message } \\
\text { content }\end{array}$ & $\begin{array}{c}\text { Factor2: } \\
\text { Information } \\
\text { access }\end{array}$ \\
\hline Irregular power supply & $\mathbf{0 . 4 5 0}$ & 0.146 \\
Lack of needed poultry information in & $\mathbf{0 . 6 5 4}$ & 0.017 \\
newspapers, radio & 0.174 & $\mathbf{- 0 . 6 3 4}$ \\
Ambiguity nature of message content & $\mathbf{0 . 5 9 6}$ & -0.122 \\
Illiteracy of farmers & -0.134 & $\mathbf{0 . 7 1 6}$ \\
Poor access to information & 0.344 & $\mathbf{0 . 4 1 5}$ \\
Resource Endowment & 0.223 & $\mathbf{0 . 6 1 2}$ \\
Financial constraints & & -0.047 \\
Orderly preference to entertainment based to & $\mathbf{0 . 5 5 6}$ & - \\
serious news & &
\end{tabular}

Extraction Method: Principal Component Analysis.

Rotation Method: Varimax with Kaiser Normalization.

\section{Conclusion and Recommendations}

The level of mass media utilization was high for vaccination, chicks brooding, feed formulation, general housing and daily routine management but low on pen lightening. However, the effective mass media utilization was highly impeded by finance, irregular power supply and lack of needed poultry information in the mass media sources.

Government should assist farmers in the area of adult literacy education and basic skill acquisition so that farmers can effectively make use of different mass media for poultry farming information. There is need for constant power supply, this will help in easy usage of the mass media and also enable media houses in proper delivery and effective dissemination of information. Agricultural information by the media should be based on people's needs and problems so as to get their interest in the news. Also the message content should be clear and simple. This will help in more understanding of the message to the farmers.

\section{References}

Adeyemo, A.A. \& Onikoyi, M.P. (2012). Prospects and challenges of large scale commercial poultry production in Nigeria. Agricultural Journal, 1(7), 388-393.

Akinbile, L., Akinpelu, O., \& Akwiwu, U. (2013). Risk management strategies utilized by small scale poultry farmers in Oyo State, Nigeria: Implications for agricultural transformation. Journal of Agricultural Extension, 17(1). Retrieved on 13/11/2018 from http://aesonnigeria.org/ajm/index.php/jae/article/view/47 
Creative Commons User License: CC BY-NC-ND

Abstracted by: EBSCOhost, Electronic Journals Service (EJS),

Google Scholar, Journal Seek, Scientific Commons,

Food and Agricultural Organization (FAO), CABI and Scopus
Journal of Agricultural Extension

Vol. 23 (2) April, 2019

ISSN(e): 24086851; ISSN(Print); 1119944X

http://journal.aesonnigeria.org

http://www.ajol.info/index.php/jae

Email: editorinchief@aesonnigeria.org

http://eoi.citefactor.org/10.11226/v23i2

Akinnusi, F., Sodiya, C., \& Adamu, C. (2018). Determinants of farm hygiene practices towards preventing and controlling poultry diseases among poultry farmers in Lagos State, Nigeria. Journal of Agricultural Extension, 22(2), 13-27.

Ani, A.O., Umunakwe, P.C., Ejiogu -Okereke, E.N., Nwakwasi, R.N. \& Aja, A.O.(2017). Utilization of mass media among farmers in Ikwere Local Government Area of Rivers State, Nigeria. International Journal of Agricultural Extension and Rural Development Studies, 5(2), 3544.

Ariyo, O.C, Ariyo, M.O., Okelola, O.E., Aasa, O.S., Awotide, O.G., Aaron, A.J., \& Oni, O.B. (2013). Assessment of the role of mass media in the dissemination of agricultural technologies among farmers in Kaduna North Local Government Area of Kaduna State, Nigeria. Journal of Biology, Agriculture and Healthcare, 3(6), 4-12.

Asiabaka, C.C. (2012). Agricultural extension: A handbook for development practitioners. Owerri: Nigeria, Hudson-Jude Publishers, 240.

Ayanda I. F. (2013). Capability of poultry association of Nigeria for extension services delivery to poultry farmers in Kwara State, Nigeria. Journal of Agricultural Extension, 17(2), 34-41.

Bruce, F. (2013). The Cruelest of All Factory Farm Products: Eggs From Caged Hens. Retrieved 2/4/2017 from https://en.wikipedia.org/wiki/Battery_cage

Chah, J., Odo, E., Asadu, A., \& Enwelu, I. (2013). Poultry farmers' adaptation to climate change in Enugu North Agricultural Zone of Enugu State, Nigeria. Journal of Agricultural Extension, $17(1)$.

Enwelu, I. A., Enwereuzor, S. O., Asadu, A. N., Nwalieji, H. U. \& Ugwuoke B. C. (2017). Access and use of information and communication technologies by extension workers in Anambra State Agricultural Development Programme, Nigeria. Journal of Agricultural Extension, 21 (2), 152-162.

Food and Agricultural Organizations of the United States (FAO) (2016). Animal production and health. Agriculture and consumer protection department. FAO Publication, Rome.

Hasan, S. \& Sharma, A. (2011). Print media utilization pattern among home makers. Global Media Journal-Indian Edition/Summer Issue /June. http//www.gbpuat.ac.in

Heise, H., Crisan, A., \& Theuvsen, L. (2015). The poultry market in Nigeria: Market structure and potential for investment in the market. International Food and Agribusiness Management Review (IFAMA), 18(special issue A), 197-222.

Koyenikan. M. J. (2011). Assessment of rural poultry extension services in Oshimili North Local Government Area, Delta State, Nigeria. Nigerian Journal of Animal Production, 3(9),165171.

Mbanaso, E. O., Agwu, A. E., Anyanwu, A. C., Ememandu, E., \& Asumugba, G. N. (2013). Adoption of improved sweetpotato varieties by farmers in South-East agro- ecological zone of Nigeria. In Nwara, J. C. (ed.) Proceedings of 26th annual conference of Farm Management Association of Nigeria (FAMAN) held at Michael Okpara University of Agriculture Umudike, Nigeria, October 15th - 19th, 2012. Liu house of excellent ventures, Owerri, Nigeria, pp. $137-144$.

Mgbakor, M., lyobor, O. \& Uzendu, P.O. (2013). Contributions of mass media to the development of agricultural extension in Ika North East local government area of Delta state, Nigeria. Academic Journal of Plant Sciences , 6(3), $127-133$. 
Creative Commons User License: CC BY-NC-ND

Abstracted by: EBSCOhost, Electronic Journals Service (EJS),

Google Scholar, Journal Seek, Scientific Commons,

Food and Agricultural Organization (FAO), CABI and Scopus
Journal of Agricultural Extension

Vol. 23 (2) April, 2019

ISSN(e): 24086851; ISSN(Print); 1119944X

http://journal.aesonnigeria.org

http://www.ajol.info/index.php/jae

Email: editorinchief@aesonnigeria.org

http://eoi.citefactor.org/10.11226/v23i2

National Center for Biotechnological Information (NCBI) (2016). Entry in re3data.org. www.re3data.org. USA. Retrieved 21 August, 2017.

Okwu, O.J. \& Iorkaa, T.I. (2011). An assessment of farmers' use of new information and communication technologies as sources of agricultural information in Ushongo Local Government Area, Benue State, Nigeria. Journal of Sustainable Development in Africa, 13(2), 32-40.

Oladeji, J. O. (2011). Sources and utilization of poultry production information among poultry farmers in Oyo State. International Journal of Livestock Production, 2 (2), 11 - 016.

Olagunju F. I. \& Babatunde R. O. (2011). Impact of credit on poultry productivity in southwestern Nigeria. ARPN Journal of Agricultural and Biological Science, 6(10), 58-65.

Sharma, D. (2012). Mass Media utilization pattern of farm Women. International Journal of Scientific and Research Publications, 2(5) May, 50-63.

World Bank. (2011). ICT in agriculture: connecting smallholders to knowledge, networks and institutions. World Bank, Washington, D.C. 